\title{
Gastric secretion in relation to subsequent duodenal ulcer and familial history
}

\author{
J. H. BARON ${ }^{1}$ \\ From the Institute of Clinical Research, Middlesex Hospital Medical School, London
}

EDITORIAL SYNOPSIS This paper reports a follow-up of 91 healthy men who had a histamine gastric function test performed 28 years ago and relates the original gastric function test to the subsequent development of duodenal ulceration.

Patients with duodenal ulcer secrete more acid gastric juice than normal subjects both at rest and after stimuli such as histamine. It is not yet established whether this hypersecretion precedes or follows the development of duodenal ulceration. The only possible method for solving this problem is by determining the fate of subjects whose gastric secretion is known.

Lee Lander and Maclagan (1934) measured the volume and free acidity (and their product, output of free acid) of gastric secretion in the hour after the injection of $0.75 \mathrm{mg}$. histamine (approximately $0.01 \mathrm{mg}$. per $\mathrm{kg}$. body weight) in 100 healthy medical students at this medical school. Doll, Avery Jones, and Maclagan (1949) obtained the subsequent medical history of 86 of these students. No subject had developed a proved duodenal or gastric ulcer. Ten men had histories suggestive of peptic ulcer (assessed by Dr. Avery Jones who had no knowledge of the subjects' gastric secretion). The mean volume of gastric juice secreted per hour by these 10 men was significantly higher $(0.01<P<0.02)$ than that secreted by the others. None of the five subjects who secreted less than $100 \mathrm{ml}$. of gastric juice per hour had developed ulcer-like symptoms. There was no significant difference $(0.7<P<0.8)$ in the maximum free acidity of the gastric juice nor in the amount of free acid secreted per hour $(0.05<\mathrm{P}<0.10)$ between the 10 who developed ulcer-like symptoms and the others.

Doll et al. concluded that increased gastric secretion predisposes to the development of ulcerlike symptoms, and 'the results support the view that hypersecretion is a causal change rather than an effect of peptic ulcer'. In 1948 the average age of these doctors was 37 , so that it was not surprising that in

'Leverhulme research scholar. none had peptic ulcers been proved. From this series no conclusion could be drawn about the relationship between gastric secretion and duodenal ulceration. A further enquiry was therefore made in 1961 (when the average age of the doctors was 50) to see if proved duodenal ulcers had now been found and if the occurrence of these ulcers could be correlated with gastric secretion 28 years earlier. In the course of this enquiry the opportunity was taken to check on any familial factors in gastric secretion.

Of the 100 original subjects, three are known to have died and the addresses of five others could not be traced: 91 of the remaining 92 have answered a questionnaire about their subsequent medical history. Their answers have been classified into the following groups:-

1 Sixty-nine doctors had never had dyspepsia, defined in the questionnaire as 'any recurrent indigestion or dyspepsia, e.g., bouts of epigastric pain or heartburn lasting at least a week'.

2 Thirteen doctors gave a history of indigestion of some kind, for which no definite diagnosis had been made. Six of these patients had had barium meal $x$-ray examinations, which had all been normal. No attempt was made to decide whether the patients' symptoms were suggestive of peptic ulceration.

3 Two doctors had recurrent indigestion which had been attributed to a hiatus hernia and oesophageal reflux shown on barium meals.

4 Seven doctors had duodenal ulcers which had been shown by radiographs. None of these had been treated surgically.

The results of the original gastric function tests of these 91 subjects are shown in Table I. The seven subjects who were later to develop proved duodenal ulcers secreted a larger volume of gastric juice, of higher acidity, than did 69 subjects who were to remain free of dyspepsia for the next 28 years. 
TABLE I

GASTRIC SECRETION AND SUBSEQUENT SYMPTOMS

\begin{tabular}{|c|c|c|c|c|c|c|c|c|c|c|c|c|c|}
\hline \multirow[t]{2}{*}{$\begin{array}{l}\text { Symptoms after Test } \\
\text { Meal in } 91 \text { Subjects }\end{array}$} & \multirow[t]{2}{*}{$\begin{array}{l}\text { No. in } \\
\text { Group }\end{array}$} & \multicolumn{4}{|c|}{$\begin{array}{l}\text { Highest Free Acid } \\
(\mathrm{ml} . \mathrm{N} / 10 \mathrm{HCl} / 100 \mathrm{ml} . \text { juice })\end{array}$} & \multicolumn{4}{|c|}{$\begin{array}{l}\text { Volume of Juice } \\
\text { (ml./hour) }\end{array}$} & \multicolumn{4}{|c|}{$\begin{array}{l}\text { Amount of Free Acid }{ }^{3} \\
(\mathrm{ml} . \mathrm{N} / 10 \mathrm{HCl} \text { per hour })\end{array}$} \\
\hline & & Mean & Range & S.D. & S.E. & Mean & Range & S.D. & S.E. & Mean & Range & S.D. & S.E. \\
\hline $\begin{array}{l}\text { No dyspepsia } \\
\text { Dyspepsia (no definite }\end{array}$ & 69 & $103 \cdot 4$ & $47-141$ & $23 \cdot 9$ & $2 \cdot 9$ & $197 \cdot 8$ & $50-340$ & $55 \cdot 0$ & 6.6 & $183 \cdot 1$ & $40-327$ & $69 \cdot 5$ & $8 \cdot 4$ \\
\hline diagnosis) & 13 & $101 \cdot 9$ & $10-130$ & $34 \cdot 7$ & $9 \cdot 6$ & $202 \cdot 5$ & $40-330$ & $62 \cdot 2$ & $17 \cdot 3$ & 196.9 & $7-310$ & $84 \cdot 7$ & $23 \cdot 5$ \\
\hline Hiatus hernia (proved) & 2 & $125 \cdot 0$ & $120-130$ & - & - & $173 \cdot 5$ & $147-200$ & - & - & 192.0 & $154-230$ & - & - \\
\hline Duodenal ulcer (proved) & 7 & $108 \cdot 0$ & $69-140$ & $21 \cdot 6$ & $8 \cdot 2$ & 213.4 & $150-270$ & $37 \cdot 0$ & $14 \cdot 0$ & $205 \cdot 0$ & $130-277$ & $48 \cdot 8$ & $18 \cdot 5$ \\
\hline
\end{tabular}

${ }^{1} \mathrm{ml}$. N/10 HCl per $100 \mathrm{ml}$. juice $\equiv$ clinical units $\equiv \mathrm{mEq} . / 1$. 'free acid'.

${ }^{2}$ Volume of juice per hour was measured as $1.5 \times$ volume secreted in the peak output period 10 to 50 minutes after the injection of histamine. ${ }^{3} \mathrm{ml}$. $\mathrm{N} / 10 \mathrm{HCl}$ per hour $\equiv 10 \times \mathrm{mEq}$. 'free $\mathrm{HCl}$ '.

Comparing duodenal ulcer with those with no dyspepsia:- Highest free acid $\quad \mathrm{t}=0.489 \mathrm{n}=74 \quad \mathrm{P}>0.6$ Volume of juice/hour $\quad t=0.732 \quad n=74 \quad P>0.4$ Amount of free acid/hour $t=0.803 \quad n=74 \quad P>0.4$

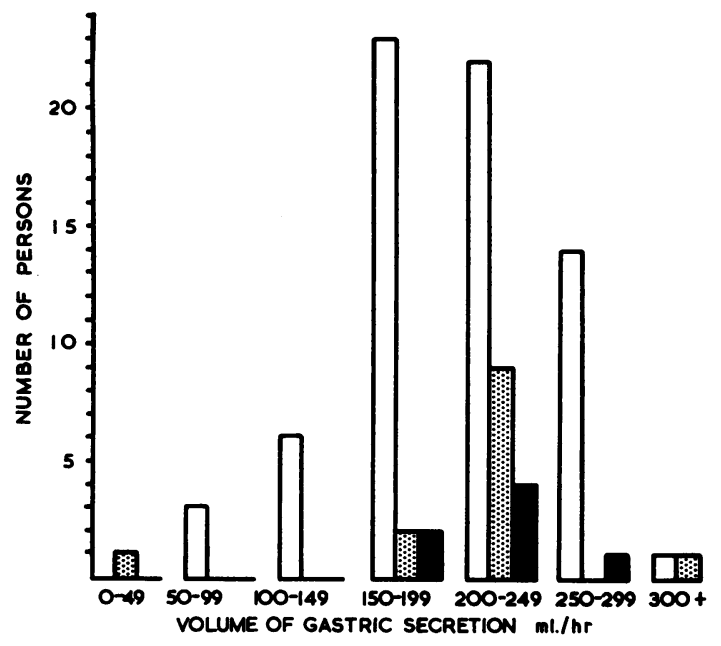

FIG. 1. Volume of gastric juice and development of subsequent symptoms. Open columns, no dyspepsia or peptic ulceration; stippled columns, dyspepsia (no definite diagnosis); solid columns, proved duodenal ulceration.

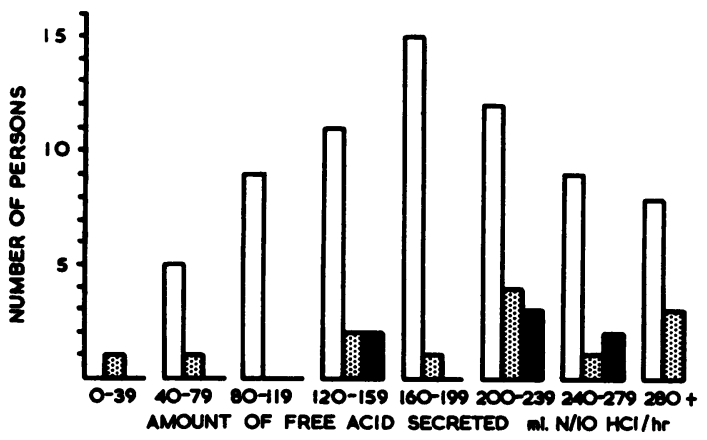

FIG. 2. Amount of free acid and development of subsequent symptoms (notation as in Fig. 1).
These differences are not statistically significant for any of these measurements but may be on account of the small numbers involved.

The variation in the volume of juice secreted is shown in Fig. 1 as the frequency distribution of the individual results, omitting the two men with hiatus hernia. None of the 10 subjects who secreted less than $150 \mathrm{ml}$. gastric juice per hour have so far developed duodenal ulceration; one has dyspepsia. Thus $13 \%(9 / 69)$ of dyspepsia-free subjects secreted less gastric juice than the least volume secreted by a subject who later developed a duodenal ulcer.

The variation in the amount of free acid secreted is shown in Fig. 2 as the frequency distribution of the individual results. Here $22 \%(15 / 69)$ of the dyspepsiafree subjects secreted less acid than the least amount secreted by a subject who later developed a duodenal ulcer.

\section{FAMILY HISTORY}

There is a strong familial tendency in duodenal ulcer (Doll and Buch, 1950; Doll and Kellock, 1951), and theoretically hypersecretion could be familial, or lack of mucosal resistance could be familial. Twenty of Lee Lander and Maclagan's students had one or both parents with either peptic ulcer or severe dyspepsia of long standing. These 20 students secreted significantly more $(P<0.01)$ gastric juice and more acid than did 80 students neither of whose parents had peptic ulcer or dyspepsia.

In the questionnaire sent to these subjects in 1961 the opportunity was taken to re-examine the familial factors in gastric secretion, and the doctors were asked if any of their first-degree relatives (father, mother, brother, sister, or child) had had minor or severe indigestion, proved gastric, duodenal, or stomal ulcers, carcinoma of the stomach, chronic hypochromic or pernicious anaemia. The 91 replies have been classified into the following groups:-

Fifty-three doctors had no family history of 
TABLE II

GASTRIC SECRETION AND FAMILY HISTORY OF DYSPEPSIA IN 91 SUBJECTS

\begin{tabular}{|c|c|c|c|c|c|c|c|c|c|c|c|c|c|}
\hline \multirow[t]{2}{*}{$\begin{array}{l}\text { Family History of } \\
\text { First-Degree Relatives }\end{array}$} & \multirow[t]{2}{*}{$\begin{array}{l}\text { No. in } \\
\text { Group }\end{array}$} & \multicolumn{4}{|c|}{$\begin{array}{l}\text { Highest Free Acid } \\
\text { (ml. N/10 HCl/100 ml. juice) }\end{array}$} & \multicolumn{4}{|c|}{$\begin{array}{l}\text { Volume of Juice } \\
\text { (ml./hour) }\end{array}$} & \multicolumn{4}{|c|}{$\begin{array}{l}\text { Amount of Free Acid } \\
(\mathrm{ml} . \mathrm{N} / 10 \mathrm{HCl} \text { per hour) }\end{array}$} \\
\hline & & Mean & Range & S.D. & S.E. & Mean & Range & S.D. & S.E. & Mean & Range & S.D. & S.E. \\
\hline \multirow{5}{*}{$\begin{array}{l}\text { No dyspepsia, ulcers, } \\
\text { or anaemia } \\
\text { Minor or severe dyspepsia } \\
\text { (no definite diagnosis) } \\
\text { Hiatus hernia (proved) } \\
\text { Chronic hypochromic and } \\
\text { pernicious anaemia, } \\
\text { Carcinoma of stomach } \\
\text { Gastric ulcer (proved) } \\
\text { Duodenal ulcer (proved) }\end{array}$} & 53 & $105 \cdot 2$ & $47-141$ & $24 \cdot 3$ & $3 \cdot 3$ & $201 \cdot 1$ & $50-340$ & $54 \cdot 8$ & $7 \cdot 5$ & $184 \cdot 1$ & $40-310$ & 66.6 & $9 \cdot 1$ \\
\hline & $\begin{array}{r}17 \\
2\end{array}$ & $\begin{array}{r}94 \cdot 6 \\
102 \cdot 0\end{array}$ & $\begin{array}{l}10-130 \\
97-107\end{array}$ & $33 \cdot 3$ & $\begin{array}{c}8 \cdot 1 \\
--\end{array}$ & $\begin{array}{l}189 \cdot 7 \\
222.0\end{array}$ & $\begin{array}{r}40-279 \\
214-230\end{array}$ & $63 \cdot 5$ & $15 \cdot 4$ & 173.5 & 7-327 & $89 \cdot 4$ & $21 \cdot 7$ \\
\hline & & & $9 /-107$ & & & $222 \cdot 0$ & & & - & $178 \cdot 0$ & $149-207$ & - & - \\
\hline & $\begin{array}{l}5 \\
8 \\
6\end{array}$ & $\begin{array}{l}112 \cdot 0 \\
105 \cdot 1\end{array}$ & $\begin{array}{r}103-129 \\
60-140\end{array}$ & $15 \cdot 6$ & $\begin{array}{l}7 \cdot 0 \\
8 \cdot 3\end{array}$ & $\begin{array}{l}184 \cdot 2 \\
214 \cdot 5\end{array}$ & $\begin{array}{l}140-250 \\
151-290\end{array}$ & $46 \cdot 9$ & $\begin{array}{l}21 \cdot 0 \\
14 \cdot 9\end{array}$ & $192 \cdot 0$ & $\begin{array}{l}119-281 \\
111-288\end{array}$ & $55 \cdot 1$ & $24 \cdot 7$ \\
\hline & 6 & $118 \cdot 7$ & $98-130$ & $13 \cdot 1$ & $5 \cdot 3$ & $203 \cdot 3$ & $150-270$ & $37 \cdot 4$ & $15 \cdot 3$ & $219 \cdot 2$ & $140-264$ & $39 \cdot 1$ & 16.0 \\
\hline
\end{tabular}

Comparing all subjects with family history of duodenal ulcer with all those with no family history of dyspepsia or ulcers:-

Highest free acid $\quad t=1.318 \quad n=57 \quad P>0.1$

Volume of juice/hour $\quad t=0.096 \quad n=57 \quad P>0.9$

Amount of free acid/hour $t=1.242 \quad n=57 \quad P>0.2$

TABLE III

GASTRIC SECRETION AND FAMILY HISTORY OF DUODENAL ULCER IN 45 SUBJECTS WITHOUT ULCERS OR DYSPEPSIA

\begin{tabular}{|c|c|c|c|c|c|c|c|c|c|c|c|c|c|}
\hline \multirow[t]{2}{*}{$\begin{array}{l}\text { Family History of } \\
\text { First-degree Relatives }\end{array}$} & \multirow[t]{2}{*}{$\begin{array}{l}\text { No. in } \\
\text { Group }\end{array}$} & \multicolumn{4}{|c|}{$\begin{array}{l}\text { Highest Free Acid } \\
(\mathrm{ml} . \mathrm{N} / 10 \mathrm{HCl} / 100 \mathrm{ml} . \text { juice })\end{array}$} & \multicolumn{4}{|c|}{$\begin{array}{l}\text { Volume of Juice } \\
\text { (ml./hour) }\end{array}$} & \multicolumn{4}{|c|}{$\begin{array}{l}\text { Amount of Free Acid } \\
\text { ( } \mathrm{ml} . \mathrm{N} / 10 \mathrm{HCl} \text { per hour) }\end{array}$} \\
\hline & & Mean & Range & S.D. & S.E. & Mean & Range & S.D. & S.E. & Mean & Range & S.D. & S.E. \\
\hline $\begin{array}{l}\text { No dyspepsia, ulcers, or } \\
\text { anaemia } \\
\text { Duodenal ulcer (proved) }\end{array}$ & $\begin{array}{r}40 \\
5\end{array}$ & $\begin{array}{l}102 \cdot 0 \\
116 \cdot 4\end{array}$ & $\begin{array}{l}47-139 \\
98-134\end{array}$ & $\begin{array}{l}25 \cdot 8 \\
27 \cdot 7\end{array}$ & $\begin{array}{r}4 \cdot 1 \\
12 \cdot 4\end{array}$ & $\begin{array}{l}195 \cdot 0 \\
208 \cdot 0\end{array}$ & $\begin{array}{r}50-340 \\
150-270\end{array}$ & $\begin{array}{l}60 \cdot 1 \\
39 \cdot 2\end{array}$ & $\begin{array}{r}9 \cdot 5 \\
17 \cdot 5\end{array}$ & $\begin{array}{l}175 \cdot 6 \\
219 \cdot 2\end{array}$ & $\begin{array}{r}43-310 \\
140-264\end{array}$ & $\begin{array}{l}69 \cdot 7 \\
47 \cdot 9\end{array}$ & $\begin{array}{l}11 \cdot 0 \\
21 \cdot 4\end{array}$ \\
\hline
\end{tabular}

Comparing dyspepsia-free subjects with family history of duodenal ulcer with those with no family history of dyspepsia, ulcer, or anaemia:Highest free acid $\quad t=1.202 \quad n=43 \quad P>0.2$

Volume of juice/hour $\quad t=0.460 \quad n=43 \quad P>0.6$

Amount of free acid/hour $t=1.337 \quad n=43 \quad P>0.1$

dyspepsia or ulcers, and 40 of them had not had ulcers or indigestion themselves.

Seventeen doctors had first-degree relatives who had dyspepsia (10 minor, six severe) for which no definite diagnosis had been made.

Two doctors' mothers had had proved hiatus hernia.

Three doctors' mothers had chronic anaemia (two pernicious anaemia, one chronic hypochromic).

Two doctors' parents had had a carcinoma of the stomach.

Eight doctors' first-degree relatives had proved gastric ulcers.

Six doctors' first-degree relatives had proved duodenal ulcers. One of these six doctors had a duodenal ulcer himself; the other five had never had any form of indigestion themselves.

The results of the original gastric function tests are shown in Table II. The six subjects whose firstdegree relatives had duodenal ulcer secreted more acid than did the 53 subjects with no history of indigestion in their immediate family, but in no case were these differences statistically significant.
Of the 69 doctors who had never had dyspepsia or ulcers themselves, 24 had a family history of minor dyspepsia, anaemia, or gastric ulcer or carcinoma.

Table III shows that in 45 subjects without indigestion, five with first-degree relatives with duodenal ulcer secreted more gastric juice of higher acidity and thus more acid than $\mathbf{4 0}$ with no family history of ulcers, dyspepsia, or anaemia, but again the differences are not significant.

\section{DISCUSSION}

This investigation has not answered the question, 'Does hypersecretion precede or follow duodenal ulceration?' as there is an almost even probability that the differences shown could have been due to chance. If about one in seven men have duodenal ulceration during their lives one would expect about 13 of these 91 doctors to have duodenal ulcers some time. Those with dyspepsia now may later be proved to have ulcers, and some of those now free of dyspepsia may develop it. A follow-up study in the future might answer the problem unequivocally, and 
studies should be done by other medical schools which have similar data.

Duodenal ulcers have developed only in those whose acid outputs were above the lowest fifth $(15 / 69=22 \%)$. The slightness of this discrimination is due to the limitations of the old submaximal dose of histamine $(0.01 \mathrm{mg} . / \mathrm{kg}$.). For example, one can estimate from Polland (1933) that $29 \%(111 / 384)$ of normal men secreted less acid than those of a similar age with duodenal ulcers. With the 'maximum' ( $0.04 \mathrm{mg} . / \mathrm{kg}$.) dose of histamine (Kay, 1953) there is greater discrimination and about twofifths of normal men secrete less acid than the least secreted by a patient with a duodenal ulcer (Baron, unpublished data). Ideally, one would like to study now a somewhat larger number of medical students with an augmented histamine test and follow them during their lives.
I wish to thank Dr. Lee Lander and Professor Maclagan for allowing me to use the results of their tests, and all the doctors for their cooperation in completing the questionnaire. I am grateful to Dr. Doll for much helpful advice. I wish to thank the Clinical Research Committee of the Middlesex Hospital Medical School for facilities at The Institute of Clinical Research.

\section{REFERENCES}

Doll, R., and Buch, J. (1950). Hereditary factors in peptic ulcer. Ann. Eugen., 15, 135-146.

- Jones, F. A., and Maclagan, N. F. (1949). Gastric secretion and subsequent dyspepsia-a follow-up study. Lancet, 2, 984-5.

, and Kellock, T. D. (1951). The separate inheritance of gastric and duodenal ulcers. Ann. Eugen., 16, 231-240.

Kay, A. W. (1953). Effect of large doses of histamine on gastric secretion of $\mathrm{HCl}$. Brit. med. J., 2, 77-80.

Lander, F. P. L., and Maclagan, N. F. (1934). One hundred histamine test meals on normal students. Lancet, 2, 1210-13.

Polland, W. S. (1933). Histamine test meals. An analysis of 988 consecutive tests. Arch. intern. Med., 51, 903-919. 